\title{
Copy number polymorphism in plant genomes
}

\author{
Agnieszka Żmieńko • Anna Samelak • Piotr Kozłowski • \\ Marek Figlerowicz
}

Received: 24 April 2013 / Accepted: 12 August 2013 / Published online: 29 August 2013

(C) The Author(s) 2013. This article is published with open access at Springerlink.com

\begin{abstract}
Copy number variants (CNVs) are genomic rearrangements resulting from gains or losses of DNA segments. Typically, the term refers to rearrangements of sequences larger than $1 \mathrm{~kb}$. This type of polymorphism has recently been shown to be a key contributor to intra-species genetic variation, along with single-nucleotide polymorphisms and short insertion-deletion polymorphisms. Over the last decade, a growing number of studies have highlighted the importance of copy number variation $(\mathrm{CNV})$ as a factor affecting human phenotype and individual CNVs have been linked to risks for severe diseases. In plants, the exploration of the extent and role of CNV is still just beginning. Initial genomic analyses indicate that CNVs are prevalent in plants and have greatly affected plant genome evolution. Many CNV events have been observed in outcrossing and autogamous species. CNVs are usually found on all chromosomes, with CNV hotspots interspersed with regions of very low genetic variation. Although $\mathrm{CNV}$ is mainly associated with intergenic regions, many $\mathrm{CNVs}$ encompass protein-coding genes. The collected data suggest that CNV mainly affects the members of large families of functionally redundant genes. Thus, the effects of individual CNV events on phenotype are usually modest. Nevertheless, there are many cases in which CNVs for specific genes have been linked to important traits such as flowering time, plant height and resistance
\end{abstract}

Communicated by R. K. Varshney.

A. Żmieńko · P. Kozłowski · M. Figlerowicz

Institute of Bioorganic Chemistry, Polish Academy of Sciences,

Noskowskiego 12/14, Poznan, Poland

A. Samelak $\cdot$ M. Figlerowicz $(\bowtie)$

Institute of Computing Science, Poznan University

of Technology, Piotrowo 2, 60-965 Poznan, Poland

e-mail: marekf@ibch.poznan.pl to biotic and abiotic stress. Recent reports suggest that CNVs may form rapidly in response to stress.

\section{Introduction}

For a long time, it was assumed that single-nucleotide polymorphisms (SNPs) and small insertion-deletion polymorphisms (indels) were the main types of DNA alterations underlying intra-species genomic variation. Quite recently, copy number variation (CNV) has been recognized as another common type of polymorphism in the genomes of humans, animals and plants. CNV results from unbalanced DNA modifications, which trigger changes in the number of copies of a particular DNA sequence. Typically, copy number variants (CNVs) encompass relatively large DNA segments (from $1 \mathrm{~kb}$ to several Mb). However, recent technical developments, especially next-generation sequencing (NGS), have enabled the identification of much shorter polymorphic regions (20-50 bp), which are traditionally defined as indels (Alkan et al. 2011).

Several mechanisms have been postulated to explain the formation of CNVs. One potential mechanism is nonallelic homologous recombination (NAHR) between DNA segments of high similarity that are not alleles. NAHR usually involves low-copy repeats (LCRs) - DNA segments larger than $1 \mathrm{~kb}$ that are generated during ancient duplication events. Depending on the LCR location, NAHR can lead to intrachromatid, interchromatid or interchromosomal rearrangements. The type of rearrangement depends on LCR orientation: the repeats may be direct, opposite or mixed. The orientation determines whether NAHR leads to the deletion, reciprocal duplication or inversion of the DNA segment flanked by the LCRs (Gu et al. 2008). Another potential mechanism is fork stalling and template switching 
(FoSTeS). FoSTeS is caused by DNA replication errors. It occurs when the replication fork stalls at one position; the nascent strand disengages from the lagging DNA template in that fork and transfers to another replication fork in close physical proximity, then re-anneals and primes DNA synthesis from that site. The template switching is driven by microhomology between the original and the invaded DNA strands. Depending on the number of switching events, the location of the invaded fork (upstream or downstream from the previously used fork) and whether the leading or lagging strand in the new fork were used as a new template, FoSTeS events may generate insertions, deletions or more complex rearrangements (Lee et al. 2007a; Zhang et al. 2009). A more detailed description of CNVs formation mechanisms can be found in the reviews of Gu et al. (2008) and Stankiewicz and Lupski (2010).

Great interest in CNVs was stimulated by the two seminal papers of Iafrate et al. (2004) and Sebat et al. (2004). Both of these papers described large-scale copy number polymorphism in the human genome. Although a few examples of $\mathrm{CNV}$ in specific genomic regions had been known previously, these papers initiated a research trend that led to the identification of thousands of CNVs, not only in the human genome but also in the genomes of other organisms, including plants. Currently, it is estimated that common CNVs occur in approximately $10 \%$ of the human reference genome. Although CNVs are more common in regions almost devoid of genes (Redon et al. 2006), they are often detected in regions that contain protein-coding genes or important regulatory elements (Fig. 1). CNVs overlapping a gene may alter the expression level of the gene by virtue of changing the number of functional copies (Fig. 1a, b, d). CNVs may also affect gene regulation by position effects, as may be the case when they encompass gene regulatory sequences, even those located several
$\mathrm{Mb}$ away (Fig. 1c). CNVs that partially overlap a gene sequence may disrupt the structure of the gene and impair its function (Fig. 1e, f).

CNVs often have phenotypic effects. In humans, variations in gene copy number have been shown to modify the risk of psoriasis (CNV affecting the $\beta$-defensin genes), HIV infection (CNV affecting the CCL3L1 gene) and osteoporosis (CNV affecting UGT2B17 gene) (Hollox et al. 2008; Yang et al. 2008; Gonzalez et al. 2005). In addition, CNVs are the most common somatic mutations observed in cancer genomes, primarily affecting the copy number of tumor suppressor genes and proto-oncogenes (Lee et al. 2007b; Frank et al. 2007; Shlien et al. 2008; Yoshihara et al. 2011; Stadler et al. 2012). CNVs in specific genome regions may be linked to some instances of autism, schizophrenia, epilepsy, Parkinson's or Alzheimer's disease (Rovelet-Lecrux et al. 2006; Weiss et al. 2008; Stefansson et al. 2008; Helbig et al. 2009; Pankratz et al. 2011; Liao et al. 2012). In addition, hundreds of rare, often de novo CNV events have been shown to significantly increase autism risk in children. A recent study showed that this disorder is associated with genome instability; global increases in both common and rare large duplications were observed in the genomes of children with autism (Girirajan et al. 2013).

In contrast, CNVs in plants have not been so thoroughly studied. It is only in the last 5 years that CNVs have attracted the attention of plant biologists and geneticists, leading to the first estimates of the extent of CNV in plant genomes. In this review, we will present current knowledge about the occurrence of CNVs in model and crop plants. We will also present examples of the association of CNVs with particular plant phenotypes. As the reader will see, the definition of CNV used in plant research is broader than in human- and animal-oriented studies, in which CNV events are attributed to individual genomes. In plant genetics,
Fig. 1 Potential effects of $\mathrm{CNV}$ on gene expression. a-c Examples of CNVs that result in an elevated transcript level; d-f Examples of CNVs that result in a decreased level of the full length transcript. Gene $\mathrm{CNV}$ (complete duplication or deletion) may change an effective gene dosage $(\mathbf{a}, \mathbf{b}, \mathbf{d})$. CNV affecting an enhancer sequence may alter transcription level without change in gene copy number (c). Partial gene deletion (e) or insertion of a duplicated sequence (f) may disrupt gene structure and functionality. $P$ promoter, $G$ gene, $R$ enhancer sequence a

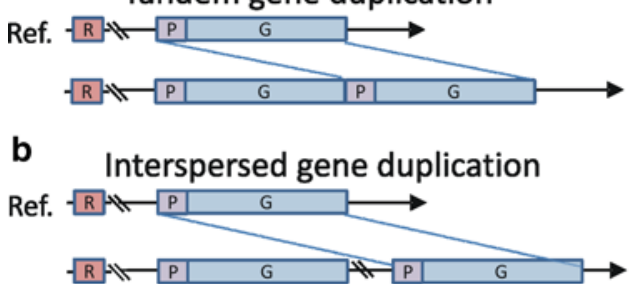

C

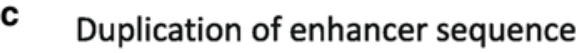

Ref.

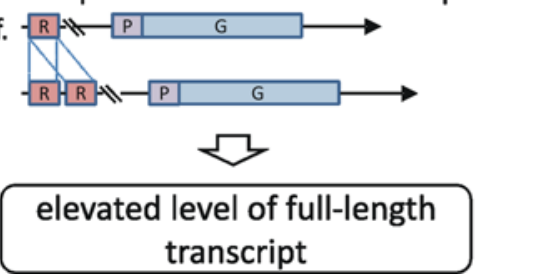

d Complete gene deletion

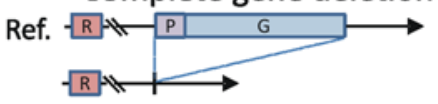

e Partial gene deletion

Ref.

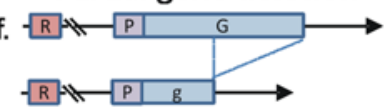

f

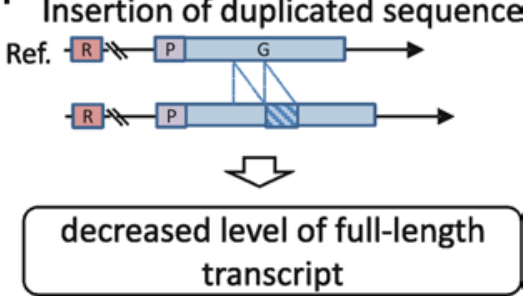


the individual organisms are mainly treated as representatives of one of the following sub-types: (1) cultivars (also named varieties), which are distinct, often intentionally bred subsets of a species that will behave uniformly and predictably when grown in the environment to which they are adapted or (2) accessions, which are collections of plant material from a particular location that are given unique identifiers (definitions after Aubry et al. 2005). This is justified by the fact that the cultivars/accessions are frequently maintained in laboratory conditions for a long time (often as inbred lines), with little influence of selective forces. In addition, many plants, including model species, are mainly self-pollinating; therefore, their genotypes are considered to be highly homozygous. Accordingly, CNVs in plants are often recognized and discussed as polymorphisms distinguishing cultivars/accessions of one species rather than affecting individual plants (Cao et al. 2011; Xu et al. 2011; Chia et al. 2012). Nevertheless, intracultivar heterogeneity is a recognized phenomenon, especially among crop plants, and some (relatively few) studies have been devoted to the exploration of genetic variation among individuals (DeBolt 2010; Ossowski et al. 2010; Haun et al. 2011).

There is, however, one more issue that needs to be highlighted in the context of CNV analysis: polyploidy. Because of whole-genome duplication events in the evolutionary history of most plant species, polyploidy is common in plants. Some of the duplicated genes may be retained as multiple copies, while other gene pairs may have diverged from each other, or some of the copies may have been lost from the homologous chromosomes. Thus, in polyploid plants, variant copy number is calculated as copies per haploid genome (Swanson-Wagner et al. 2010; Saintenac et al. 2011; Díaz et al. 2012; Cook et al. 2012), in contrast to humans and animals, in which copy number is expressed relative to the diploid genome.

\section{Methods of genome-scale CNVs detection}

Several experimental methods are used to detect CNVs: quantitative PCR, in situ fluorescent hybridization (Weaver et al. 2010), the paralogue ratio test (Armour et al. 2007), multiplex amplifiable probe hybridization (Armour et al. 2000) and multiplex ligation-dependent probe amplification (Marcinkowska-Swojak et al. 2013). Although most of these methods allow for high-throughput genotyping of a particular variant in multiple DNA samples, they are not suitable for a genome-scale analysis and have limited use in CNVs discovery. Current experimental approaches for genome-scale CNVs discovery and genotyping are mainly based on microarrays and NGS. These methods have been recently extensively reviewed in the literature (Yau and Holmes 2008; Medvedev et al. 2009; Alkan et al. 2011).
Two genome-scale methods have had the greatest impact on $\mathrm{CNV}$ research in plants: array-based comparative genome hybridization (CGH) and reference genome-based NGS. In the CGH approach, DNA probes are immobilized on an array, which enables simultaneous hybridization and detection of target sequences with a resolution that depends on the number and type of immobilized probes. Analysis of copy number is based on the relative amounts of signal from tested and reference genomic DNA samples binding to the probes. The reference sample in CGH analysis is usually the genomic DNA of the species (or accession) for which the microarray probes were designed. The ability of the assay to detect a particular region in the tested genome depends on its homology to the array probes. For this reason, CGH is always biased toward the detection of deletions (relative to the reference genome sequence), whereas DNA segments present in the tested genome but not in the reference remain undetected due to a lack of representative probes. Moreover, lower signal intensity observed for the tested genome may result not only from CNVs but also from other types of sequence polymorphisms that affect probe hybridization and produce a signal imbalance, resulting in false positive errors (Springer et al. 2009).

The second approach-NGS—is a high-throughput DNA sequencing technology. Modern NGS platforms, such as Illumina or $\mathrm{ABI} / \mathrm{SOLID}$, generate tens of millions of short reads in parallel (usually shorter than $100 \mathrm{nt}$ ) from the genomic DNA template. Signatures of CNVs in NGS data can be obtained by one of the four analytical approaches, or by a combination of them. Analysis of relative increases and decreases in sequence coverage by short reads (readdepth method) provides information about duplications and deletions. It allows for calculating the absolute copy numbers of genomic segments. Although typical analysis pipelines for NGS data involve mapping the reads to a reference genome, de novo assembly of the non-mapping reads (assembly method) allows for the discovery of new sequence variants that are not represented in the reference DNA. Additional information comes from the analysis of paired-end reads, which provide estimates of the distances between two reads and their orientation (read pair method), thereby allowing for the detection of insertions, deletions and inversions. In the case of longer reads, the exact breakpoints of all variant classes may be detected when the reads map discontinuously to the reference genome (split read method). The NGS approach has been proven effective for the discovery and mapping of structural variants at nucleotide-resolution in plants, animals and humans (Daines et al. 2009; Yoon et al. 2009; Mills et al. 2011; Cao et al. 2011; Bickhart et al. 2012). The main drawbacks of NGS are the following: difficulty with mapping short reads to DNA repeats (Treangen and Salzberg 2011) and platform-specific biases, which result in lower read coverage of some 
parts of the genome (for example, GC-rich regions) (Dohm et al. 2008). This type of sequencing also remains quite expensive.

\section{CNVs are prevalent in plant genomes}

There is growing evidence that CNVs are prevalent in plant genomes (Table 1). The first plant species that has been extensively genotyped for CNVs is maize. Three important studies used $\mathrm{CGH}$ for $\mathrm{CNV}$ s detection with maize inbred line B73 as the reference genome for probe design and as the CGH reference (Springer et al. 2009; Beló et al. 2010; Swanson-Wagner et al. 2010). The first study used a high-resolution genome tiling array to detect CNVs in inbred line Mo17 (Springer et al. 2009). The two following studies were focused on gene-coding regions only and involved multiple maize lines: 13 lines in a study by Beló et al. (2010) and 19 in a study by Swanson-Wagner et al. (2010), who also assayed 14 lines of the wild maize relative, teosinte (Z. mays ssp. parviglumis). Line Mo17 was analyzed in all the above studies, making it possible to compare results across studies. Springer et al. (2009) identified approximately 400 putative polymorphic regions that were present in both the B73 and Mo17 lines, but differed in the detected hybridization signal. The CNVs with higher copy number in Mo17 were covered by highly conserved probes significantly more often than the average, and they also more often contained genes or were located near genes. Variants with higher copy number in B73 were evenly distributed across the regions represented on the microarray. This difference most likely reflects different levels of homology of the coding and intergenic regions between the genomes of the tested and reference lines. It was also observed that, although CNVs were detected on most of the maize chromosomes, they were not uniformly distributed. Several highly conserved regions that exhibited few CNVs or no CNVs were located mainly near the centromeres. This distribution pattern was later confirmed by two other CGH studies (Beló et al. 2010; Swanson-Wagner et al. 2010). All three studies also described the existence of presence-absence variants-specific CNVs where DNA regions are present in one genome but missing from the other line. Due to the CGH array design, the detected variants more often indicated decrease in copy number or complete deletion in the tested genome, relative to the B73 reference. Beló et al. (2010) reported that $57 \%$ of all CNVs detected in their study occurred in lower copy number in the non-B73 lines. Swanson-Wagner et al. (2010) identified seven times more copy-loss events than copy gain events in the tested genomes, including presence-absence variants. One of the biggest presence-absence regions of this type, $2.6 \mathrm{Mb}$ in size, located on the short arm of chromosome 6 and spanning 25 maize genes, has been shown to be missing from multiple maize inbred lines (Springer et al. 2009; Swanson-Wagner et al. 2010; Beló et al. 2010).

Recently, the CGH method has also been applied to CNV detection in several model plant species and-similarly to the maize studies-has provided mainly examples of gene copy loss in the tested genomes. Among the 641 identified CNVs that distinguished two rice cultivars, Nipponbare (O. sativa ssp. japonica) and Guang-lu-ai 4 (O. sativa ssp. indica), the majority of $\mathrm{CNVs}$ indicated copy loss of genomic segments in Guang-lu-ai 4 (Yu et al. 2011). The exact rate of deletions in the Nipponbare cultivar could not be estimated, as the oligonucleotide array used in this study was designed to represent only the japonica cultivar. The japonica and indica subspecies diverged approximately 0.4 million years ago and display a high level of DNA sequence variation (Ma and Bennetzen 2004). $\mathrm{CNVs}$ identified in rice were distributed across all 12 chromosomes and comprised $\sim 1.8 \%$ of the rice genome. The majority of CNVs were smaller than $10 \mathrm{~kb}(67.4 \%$ of variants) although larger CNVs were detected as well, up to a size of $180.7 \mathrm{~kb}$.

In soybean, a CGH study was performed to detect CNVs in three cultivars, Archer, Minsor and Noir 1, using genomic DNA of the recently sequenced Williams 82 cultivar as a reference and as a basis for array probe design (McHale et al. 2012). Several hundred CNVs, including presence-absence variants, were detected in each of the genomes tested. The median variant size was $18-23 \mathrm{~kb}$, depending on the cultivar. The CNVs in the soybean genomes had a discontinuous distribution, with very large stretches of DNA showing little or no evidence of CNV (e.g., regions covering most of chromosomes 5 and 11). As in the maize and rice CGH studies (Springer et al. 2009; Swanson-Wagner et al. 2010; Beló et al. 2010; Yu et al. 2011), the CNVs detection was biased toward copy loss in the tested cultivars.

\section{Large-scale population sequencing studies reveal adaptive dynamics of plant genomes}

Although NGS is still an expensive method, it has proven useful for population-scale genotyping studies. In humans, a large number of individual genomes have been sequenced at low coverage to catalog CNVs and determine their frequency and distribution. This huge project comprises more than 2,300 samples, including unrelated individuals and trios (parents and a child) (Mills et al. 2011). Population-scale sequencing studies are also underway in plant genetics. They mainly aim to uncover patterns of genetic variation among cultivars/accessions and to provide a data resource for association studies. In such an 


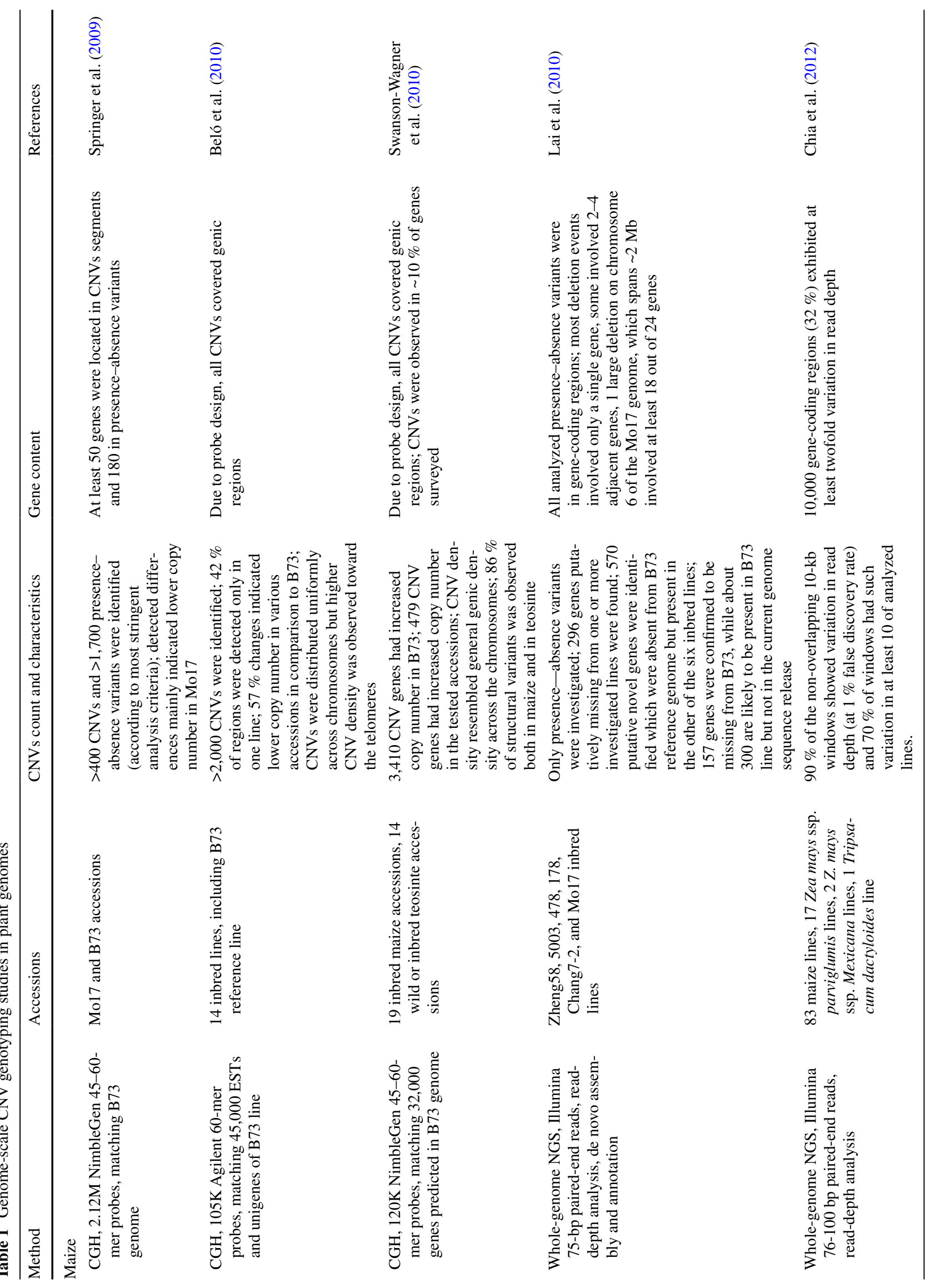




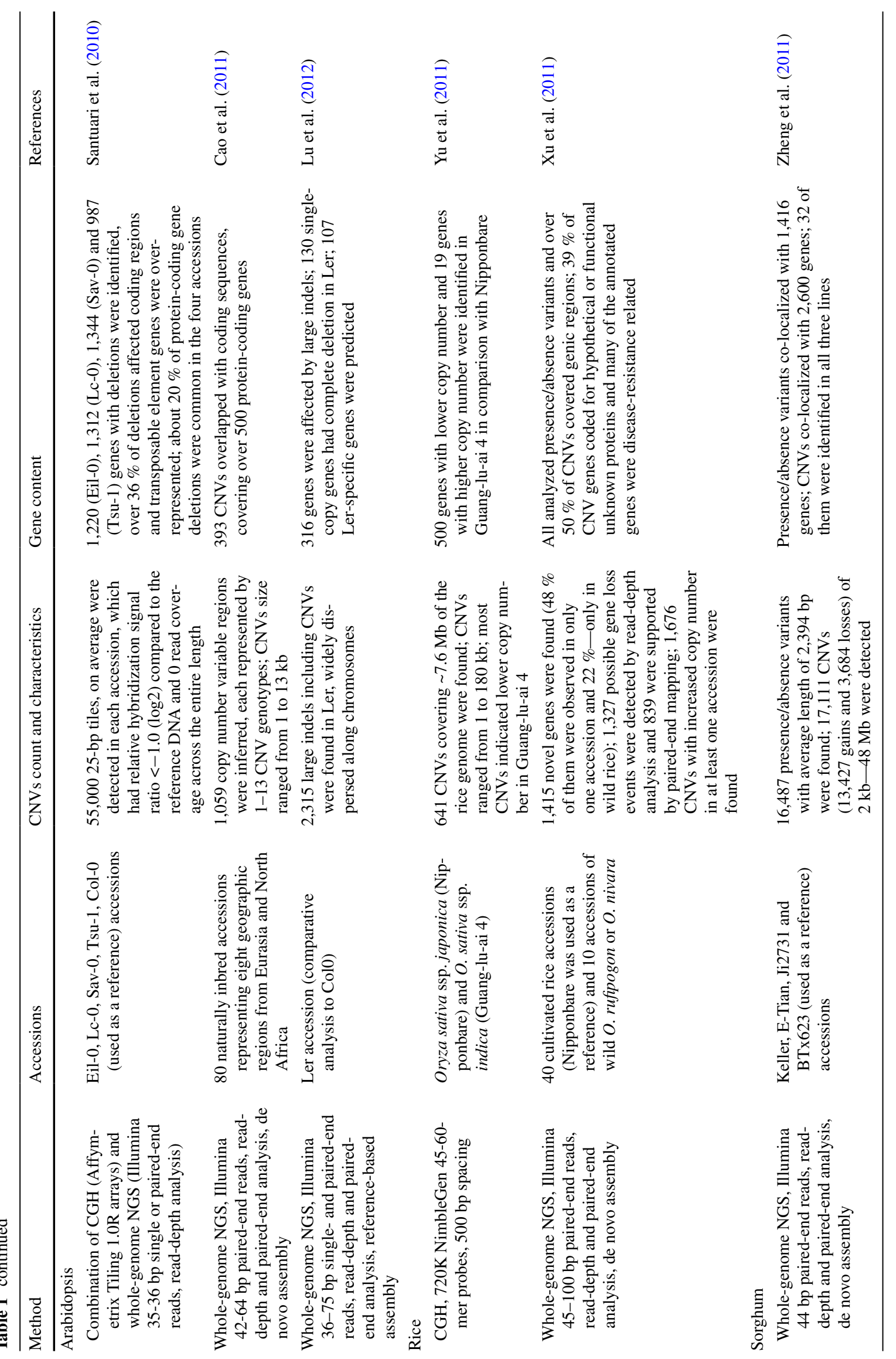




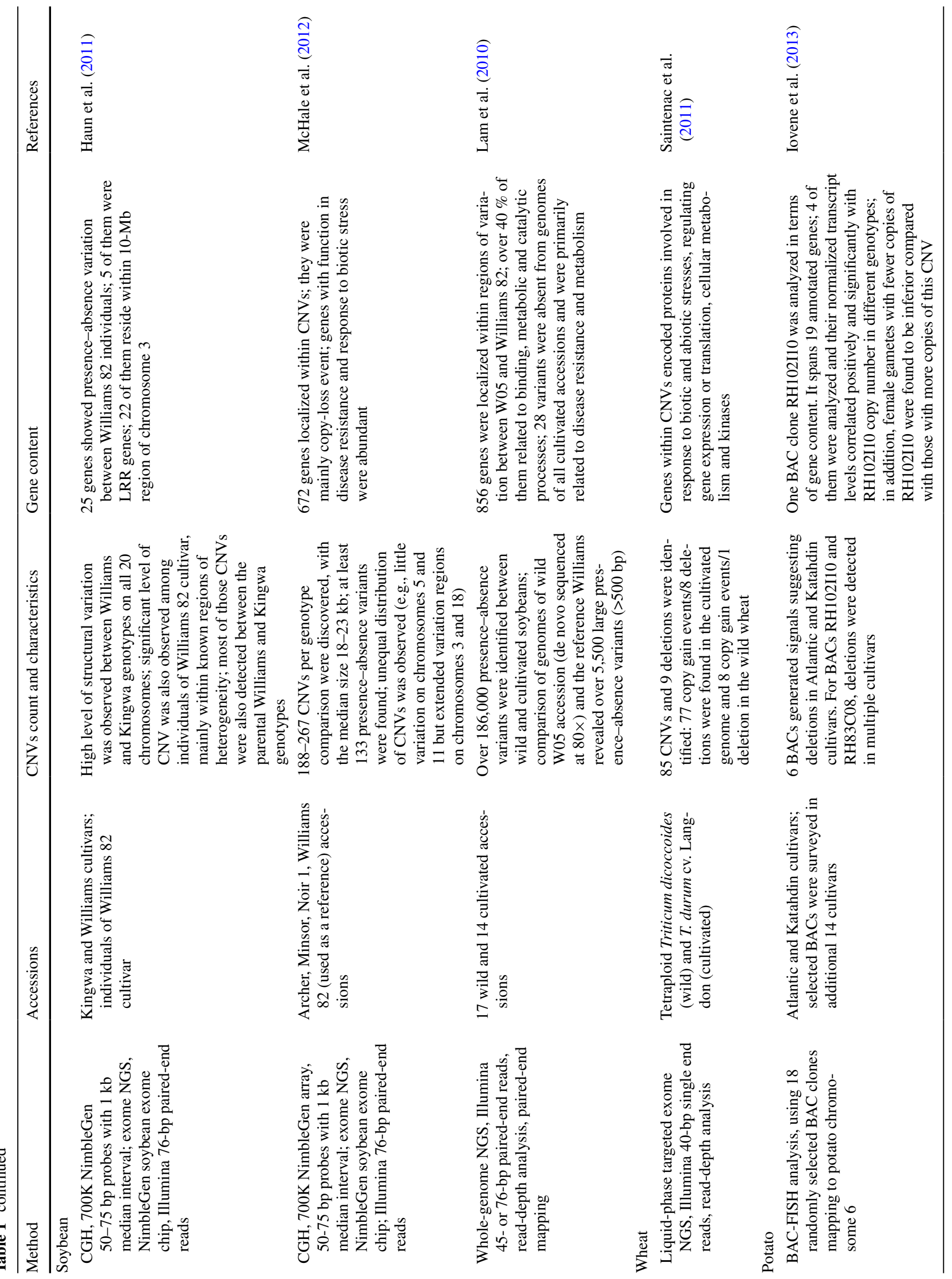


approach, individual plants are assumed to be representative of the homogenous genetic pool of a particular cultivar/ accession.

\section{Arabidopsis 1001 Genomes Project}

The 1001 Genomes Project is the largest ongoing plant genome sequencing initiative. The aim of this project, which started in 2008, is to catalog the genetic variation of Arabidopsis thaliana (Arabidopsis) by sequencing the genomes of more than 1,000 accessions (Weigel and Mott 2009). Natural Arabidopsis accessions exhibit great variation in phenotype, including features of their morphology, metabolite profiles, germination behavior, resistance to disease, and more. Accordingly, these naturally occurring inbred lines (Arabidopsis is highly self-pollinating) are considered excellent resources for studying the putative connections between genetic variation and phenotype. Data generated within the 1001 Genomes Project are made freely available to the community, enabling analysis of various aspects of the structure of the Arabidopsis genome. Currently, data for about five hundred Arabidopsis genomes have already been released (http://www.1001genomes.org/ accessions.html), and a comprehensive analysis of 80 of them has been published (Cao et al. 2011). The accessions selected for this sub-study represented six distinct geographic habitats of Arabidopsis, spanning Europe, Central Asia and North Africa. Read-depth analysis of NGS data revealed the presence of $1,059 \mathrm{CNVs}$ in the Arabidopsis genome. The detected CNVs ranged from 1 to $13 \mathrm{~kb}$ and covered $2.2 \mathrm{Mb}$ of the reference genome (approximately $2 \%)$. For $40 \%$ of those regions, 3-13 distinct copy number genotypes have been identified in the analyzed population. Over $85 \%$ of those variants were detected in more than one accession. Apart from evaluation of read depth, the authors used the read pair and assembly methods to find deletions and insertions. They detected multiple deletions ranging in size from $20 \mathrm{bp}$ to many $\mathrm{kb}$, with approximately $5 \mathrm{bp}$ precision. Finally, they managed to recover $\sim 43,000$ contigs $(0.2-9 \mathrm{~kb}$ in size) with little ( $50 \mathrm{bp})$ overlap with the reference genome (Col-0 accession). Some of those regions map to the genome of a related species, Arabidopsis lyrata, which suggests that their origin preceded Arabidopsis line divergence and that subsequent deletion events took place in the Col- 0 accession.

\section{Maize Panzea Project}

Another large-scale population sequencing effort, the Panzea project (http://www.panzea.org), is devoted to exploring genome architecture and variation in maize. The project mainly aims to identify the genetic background of complex traits in maize such as flowering, plant height and kernel quality, the control of which may result in future improvements in crop yield and sustainability (Canaran et al. 2008). In addition, the effect of domestication on the genome is being investigated by comparing maize and teosinte genomic data. Maize is a primarily outcrossing crop and displays tremendous phenotypic variation among the lines. Nearly $85 \%$ of the B73 genome is annotated as transposable elements (Schnable et al. 2009). Moreover, recent SNP analysis and RNA-sequencing approaches provided evidence of great nucleotide diversity in maize cultivars (Gore et al. 2009; Hansey et al. 2012). It is estimated that approximately $30 \%$ of the low-copy genes present in various maize inbred lines are not present in the B73 genome, which means that a substantial portion of the maize genome remains undiscovered. As explained earlier in this review, the CGH studies of maize lines, although extensive, were not devoted to discovery of this type of CNV (Springer et al. 2009; Beló et al. 2010; Swanson-Wagner et al. 2010).

In one of their recent reports, the Panzea consortium described the analysis of high-throughput sequencing data from 103 inbred maize lines, including both domesticated and wild-type lines (Chia et al. 2012). Read-depth analysis of NGS data was performed across the whole-genome sequence, using 10-kb non-overlapping windows. As much as $90 \%$ of such regions showed at least twofold variation in read depth (at a $1 \%$ false discovery rate), and $70 \%$ of the windows had such variation in at least ten of the analyzed lines. Altogether, this study showed that the genetic diversity of maize cultivars is even greater than suggested by previous estimates based on CGH studies.

\section{Rice variation catalog}

Rice is a crop of extreme agricultural importance; it is consumed in great amounts around the world. It was domesticated approximately 10,000 years ago in China, and cultivated accessions underwent substantial phenotypic changes compared to their wild ancestors. The domesticated lines can be further subdivided into several genetically distinct groups (Garris et al. 2005). As a step toward creating a comprehensive catalog of genome variation in both cultivated and wild rice, 50 accessions representing major groups of cultivated rice (ssp. indica and japonica) as well as wild rice accessions (O. rufipogon and O. nivara) were sequenced (Xu et al. 2011). Analysis of the sequencing data revealed more than 1,400 novel genes, nearly $50 \%$ of which were found only in one accession, and over $20 \%$ were specific to wild rice. A similar amount of possible gene loss events (more than 1,300) relative to the reference genome ("Nipponbare", ssp. japonica) were detected as well, most of which corresponded to unannotated proteins. In addition to presence-absence variants, nearly $1,700 \mathrm{CNVs}$ were detected, many of them $(21 \%)$ shared 
by at least five accessions. However, it should be noted that despite numerous re-sequencing projects in total involving hundreds of rice accessions, both domesticated and wildtype, little is known about CNVs in the rice genome. It is a natural consequence of the fact that most of these projects were focused mainly on SNP identification (Huang et al. 2010, 2012, 2013; Jeong et al. 2013). Accordingly, the analysis of the existing NGS data directed towards CNVs discovery may help to elucidate their impact on rice genome.

\section{CNVs commonly overlap genes}

As previously demonstrated for human and animal genomes, plant CNV density correlates with repeat density and inversely correlates with gene density (Emerson et al. 2008; Conrad et al. 2010; Chia et al. 2012). Still, numerous $\mathrm{CNVs}$ overlap protein-coding regions. The exact number of genes overlapping $\mathrm{CNVs}$ in a given species varies between experiments. For example, five different experiments in maize put the number of genes in $\mathrm{CNV}$-affected regions anywhere from 230 to more than 10,000 (Table 1). The factors that account for such differences between experiments include the following: the sensitivity of the method, the number of genes surveyed (in $\mathrm{CGH}$, the number of genes interrogated depends on the array design, in NGS it depends on library preparation, sequencing depth and accuracy of the reference genome assembly), the analysis algorithms and statistical cut-off thresholds, and the number of samples compared. Nevertheless, many CNVs were identified in at least two of the five studies. For example, high concurrence between presence-absence variations identified in Mo17 genome was observed for the CGH and NGS data (Springer et al. 2009; Lai et al. 2010). In addition, genes identified as copy number variable in multiple lines in another CGH study also showed high average variation in the NGS-based analysis (Swanson-Wagner et al. 2010; Chia et al. 2012). The latter study estimated that $32 \%$ of the genes annotated in the B73 reference genome are affected by CNVs. This is much greater than the proportion of genes affected in Arabidopsis, rice or soybean (see Table 1), and it correlates with the overall higher genetic diversity and spectacular phenotypic diversity of maize. The large number of genes overlapping the discovered CNVs may also explain, at least in part, the transcriptome variation observed among different maize lines. The semiquantitative analysis of NGS-transcriptomic data revealed that multiple transcripts differed in abundance among 21 inbred maize lines (possible classification groups were: "no", "low", "medium" or "high" expression level) (Hansey et al. 2012). In addition, many transcripts annotated in the reference genome were absent from specific lines, and in other cases, novel transcripts were found in specific lines. Swanson-Wagner et al. (2010) observed that $86 \%$ of identified CNVs are present both in wild-type and domesticated lines, suggesting that the majority of the observed gene involving $\mathrm{CNV}$ events in maize preceded domestication and that they are not the product of artificial selection. Rare CNVs (i.e., those unique to a single line) were observed frequently in teosinte. Because 10 of the 14 teosinte lines used in the cited study were segregating, the authors concluded that many naturally occurring CNVs covering gene-coding regions may be non-neutral and may, therefore, be tolerated only in the heterozygous state, whereas breeding eliminates those CNVs from the genomes of highly inbred lines. On the other hand, in the study by Beló et al. (2010), the rate of occurrence of particular gene CNVs only in a single domesticated line was calculated to be much higher-about half of all CNVs observed. Although different maize lines were genotyped in the two experiments (except for Mo17 and B73), those discrepancies point to the need for more in-depth analysis of genomic data to evaluate the range of $\mathrm{CNVs}$ occurrence in maize (and other plants) as well as the rate of maize evolution.

NB and RLK multigene families are especially prone to $\mathrm{CNV}$

According to population sequencing studies, a major fraction of genes located within CNV regions code for hypothetical or unknown proteins (Xu et al. 2011; Cao et al. 2011). Among the functionally annotated genes, those which are usually overrepresented within CNV regions are genes encoding proteins with a nucleotide binding domain (NB) and one or more leucine-rich repeat (LRR) domains (known as NB-LRR genes), as well as genes encoding receptor-like kinases (RLK). Both NB-LRR and RLK genes constitute large gene families, and many of them are functionally classified as defense-related. Not surprisingly, GO term enrichment analysis of the 672 genes located within $\mathrm{CNV}$ regions in soybean revealed that genes related to disease resistance and biotic stress response were significantly overrepresented (McHale et al. 2012). Similar observations have been made for Arabidopsis and rice, where disease resistance genes represent a significant fraction of genes in CNV regions (Xu et al. 2011; Cao et al. 2011; Lu et al. 2012). High levels of duplication ensure the variability of defense genes, and such variation is advantageous in the face of changing environmental conditions. Indeed, those genes seem to be under weaker purifying selection or under stronger diversifying selection than other duplicated genes, such as genes involved in protein translation (Korbel et al. 2008; Warren et al. 2010; Lu et al. 2012). The genes of the NB-LRR family represent the largest class of resistance $(\mathrm{R})$ genes that are involved in race-specific recognition 
of pathogen avirulence determinants. $\mathrm{R}$ genes are subject to strong selective pressure promoting coevolution with pathogen effector proteins. Depending on the presence or absence of particular pathogens, the pressure for the selection of corresponding $\mathrm{R}$ genes dramatically changes, leading to rapid evolution (Guo et al. 2011; McHale et al. 2012; Ashfield et al. 2012; Luo et al. 2012).

CNVs were reported to overlap multigene families more often than unique genes in many plant species (SwansonWagner et al. 2010; Cao et al. 2011; Xu et al. 2011; Zheng et al. 2011; Chia et al. 2012; McHale et al. 2012). Recent GO term enrichment analysis of CNVs identified by CGH in soybean suggested, however, that higher CNV frequency correlates specifically with the NB and RLK gene families, not with large gene families in general. When those genes were removed from the GO term enrichment analysis of CNVs, the frequency of large gene families overlapping CNV regions did not differ much from the overall frequency of genes within those regions (McHale et al. 2012). This suggests that the large size of a gene family is not sufficient to promote CNVs formation and that some families are more affected by copy number polymorphism than others. In addition, gene members of a given family are not equally predisposed to CNV. Genes localized in clusters, especially in tandem arrays, seem to undergo copy number changes more often than isolated family members (McHale et al. 2012), which is consistent with recombination-based mechanisms of CNV formation, although it does not exclude alternative mechanisms.

\section{Associations of CNVs with plant phenotypes}

Despite the prevalence of CNVs in plant genomes and their frequent overlap with protein-coding regions, only a few have been associated with particular phenotypes on the morphological, physiological or developmental level. Paralogous plant genes are often functionally redundant. Therefore, variations in copy number of one member of a gene family may trigger quantitative rather than qualitative changes, making the $\mathrm{CNV}$-trait association difficult to detect. Still, a growing number of reports provide evidence that copy number polymorphisms contribute to natural genetic variation and control important adaptive traits in plants (Table 2).

A good example of a CNV affecting phenotype is found in the diversity of flowering times and plant heights in wheat (Fig. 2). CNVs for the genes Vrn-Al and Ppd-B1 were shown to contribute to differences in flowering time between the wheat varieties (Díaz et al. 2012). Plants with an increased copy number of $V r n-A l$, which encodes a MADS-box transcription factor, require prolonged vernalization and exhibit intermediate or late flowering phenotypes (depending on the exact number of gene copies, see Fig. 2a). The other gene, $P p d-B 1$, belongs to a family of pseudo response regulators (PRR) and it has been shown to control photoperiod sensitivity in wheat. Wheat cultivars with only one copy of $P p d-B 1$ per haploid genome are photoperiod sensitive, whereas those with increased copy number (2-4 copies), exhibit an early flowering, day-neutral phenotype (Fig. 2b). Also in wheat, a CNV has been found to determine the extreme dwarf phenotype observed in the Aibian 1 line ( $\mathrm{Li}$ et al. 2012). In this line, tandem segmental duplication of a greater than $1 \mathrm{Mb}$ region resulted in two copies of the Rht-Dlb gene in the haploid genome. Rht-DIb codes for a truncated DELLA protein, lacking the gibberellic acid response region. The $R h t-D 1 b$ allele itself triggers plants' insensitivity to gibberellic acid and causes a $20 \%$ height reduction $(\sim 90 \mathrm{~cm}$ in Youbao line, compared to $\sim 113 \mathrm{~cm}$ in the Chinese Spring line, which is a tall wheat carrying a wild-type allele RhtDla). In Aibian 1 line, however, the presence of two copies of $R h t-D l b$ results in a greater than $70 \%$ reduction in plant height $(\sim 30 \mathrm{~cm})$ (Fig. 2c).

Several confirmed examples of a CNV link to phenotype concern plant stress tolerance (Table 2). CNV of Bot1, a boron efflux carrier gene, has been shown to play a significant role in conferring boron tolerance in barley (Sutton et al. 2007). Another report links CNV of three soybean genes with the development of nematode resistance. In this plant, the poorly characterized Rhgl locus on chromosome 18 has long been known to contribute to soybean resistance to Heterodera glycines (soybean cyst nematode, $\mathrm{SCN}$ ). Recent work by Cook et al. (2012) brought evidence that SCN resistance triggered by the $r h g l-b$ allele results from simultaneous overexpression of three clustered but nonhomologous genes: an amino acid transporter, an $\alpha$-SNAP protein and a wound-inducible domain containing protein. It seems that products of those genes act in concert to convey the resistance phenotype, although the biochemical mechanism of their cooperation remains unknown. Though $\mathrm{SCN}$-susceptible soybean varieties contain only one copy of each gene, resistant lines carrying the $r h g l-b$ allele possess up to 10 tandem copies of the gene cluster. This discovery may have direct economic impact on soybean production by enabling the selection of SCN-resistant varieties based on copy number evaluation of the Rhgl region.

\section{The pace of CNVs evolution}

Recently, Lu et al. (2012) provided direct insight into the rate of structural alterations introduced during a single round of meiosis in the Arabidopsis genome. Using the Arabidopsis qrt1 mutant (a Col/Ler F1 hybrid), the authors produced four attached pollen grains from all four meiotic 


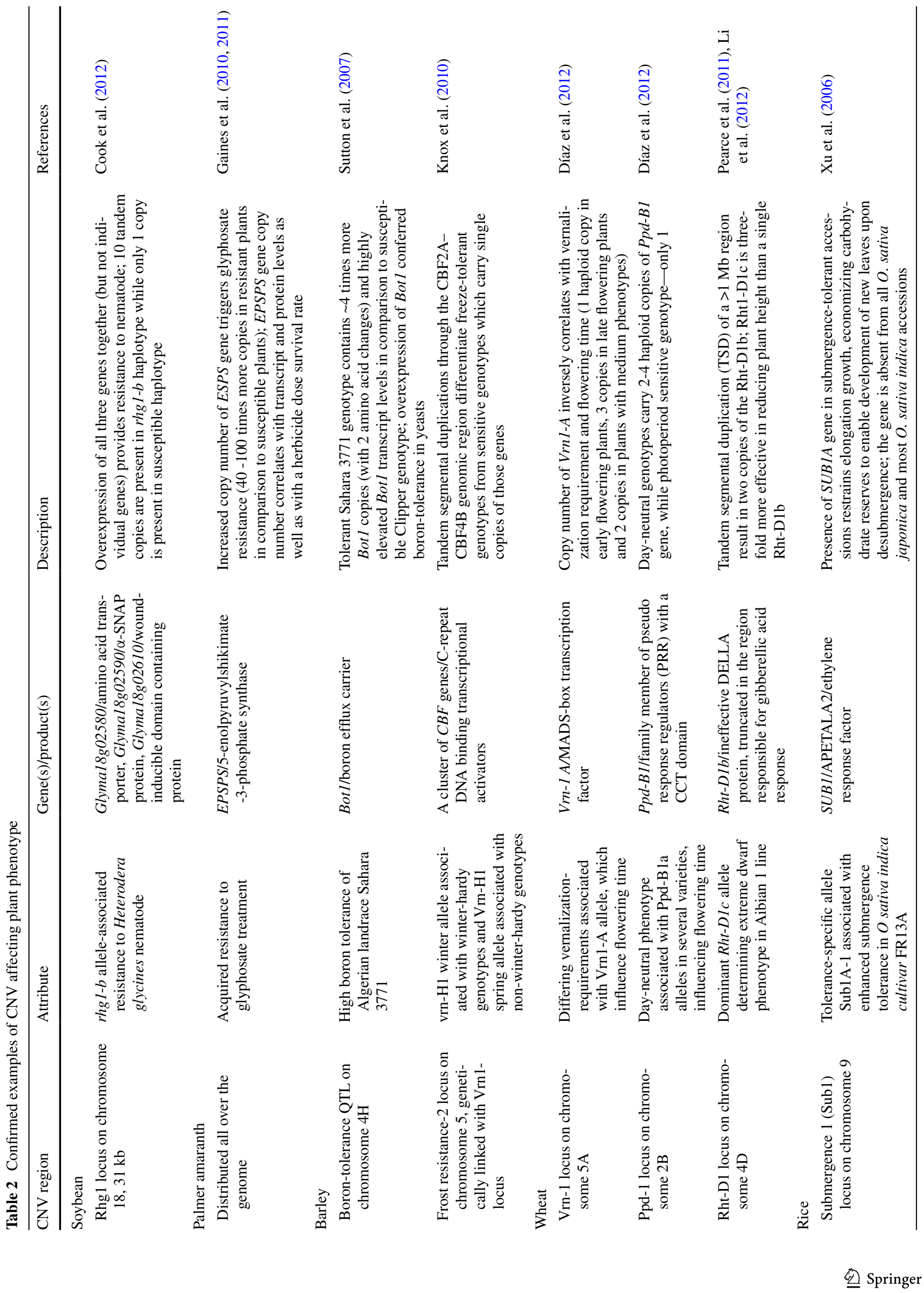




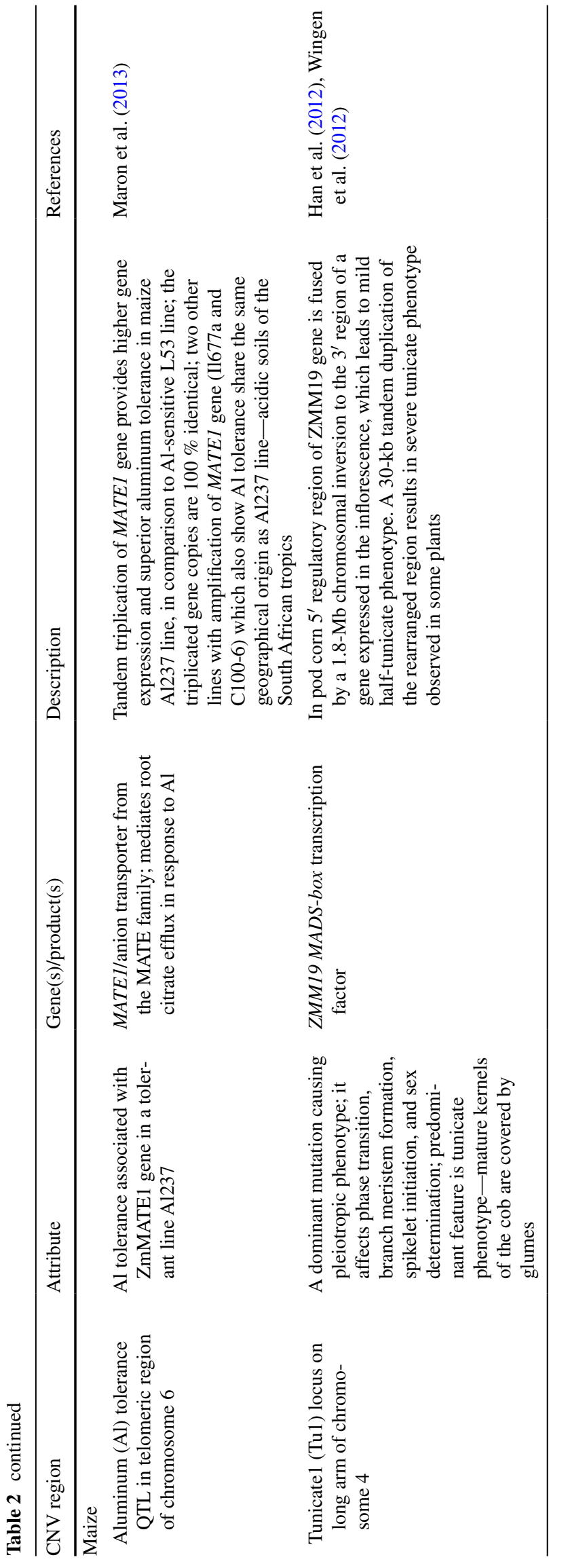

tetrads. Their progeny was obtained by pollinating a single pistil of an emasculated $\mathrm{Col}$ flower, and the genomes of the resulting plants were sequenced and analyzed. There were 21 and $32 \mathrm{CNV}$ s generated by meiotic events in the two "tetrad progeny" sets. The main cause of the CNV seemed to be NAHR-mediated reshuffling of existing highly similar sequences that map to different locations in the genome. Given that meiosis can rapidly generate CNVs among siblings (as the study of Lu et al. shows), it can be concluded that de novo CNVs are frequent in plant genomes, although the majority of them most likely do not become fixed because of strong purifying selection.

Changes in gene copy number may provide a way to rapidly alter the effective dosage of a gene, which directly affects phenotype to a variable extent. As long as the new variant is beneficial and has high selective pressure over many generations, the copy number alterations in a particular region may accumulate, and the phenotypic effects may intensify. A remarkable example of extremely fast evolution in a plant genome has been presented recently, and the case involves resistance to glyphosate in Palmer amaranth (Amaranthus palmeri) — a major weed pest in the southern part of the United States. Glyphosate is a non-selective herbicide that inhibits the activity of 5-enolpyruvylshikimate3-phosphate synthase (EPSPS), an important enzyme of the shikimate pathway in plants (Fig. 3). The shikimate pathway leads to the conversion of phosphoenol pyruvate (PEP) to chorismate- a common precursor in the biosynthesis of aromatic amino acids (Fig. 3a). The EPSPS enzyme catalyzes the biosynthesis of 5-enolpyruvylshikimate-3-phosphate (EPSP) from shikimate-3-phosphate (S3P) and PEP (Herrmann 1995) (Fig. 3b). In susceptible plants, glyphosate occupies the PEP-binding site in the EPSPS protein, acting as a competitive inhibitor of its enzymatic activity (Schönbrunn et al. 2001) (Fig. 3c). For years, glyphosate has been successfully used to control the expansion and growth of weeds, including Palmer amaranth. About 8 years ago, glyphosate-resistant populations of Palmer amaranth were detected in Georgia, and the infested area in that state and other US states has dramatically increased since then (Culpepper et al. 2006; Gaines et al. 2010). It has been shown that Palmer amaranth resistance to glyphosate is driven by an increase in EPSPS gene copy number, which is associated with increased EPSPS transcript and protein levels as well as increased glyphosate dose survival rate (Gaines et al. 2010, 2011). Resistant plants carry an increased number of EPSPS gene copies (typically between 40-100 times more than susceptible plants). The higher production of EPSPS enzyme due to the increased gene copy number enables those plants to overcome the inhibitory effect of glyphosate, most likely by providing enough enzyme molecules to bind the physiological substrate PEP, even in presence of glyphosate (Fig. 3d, e). 

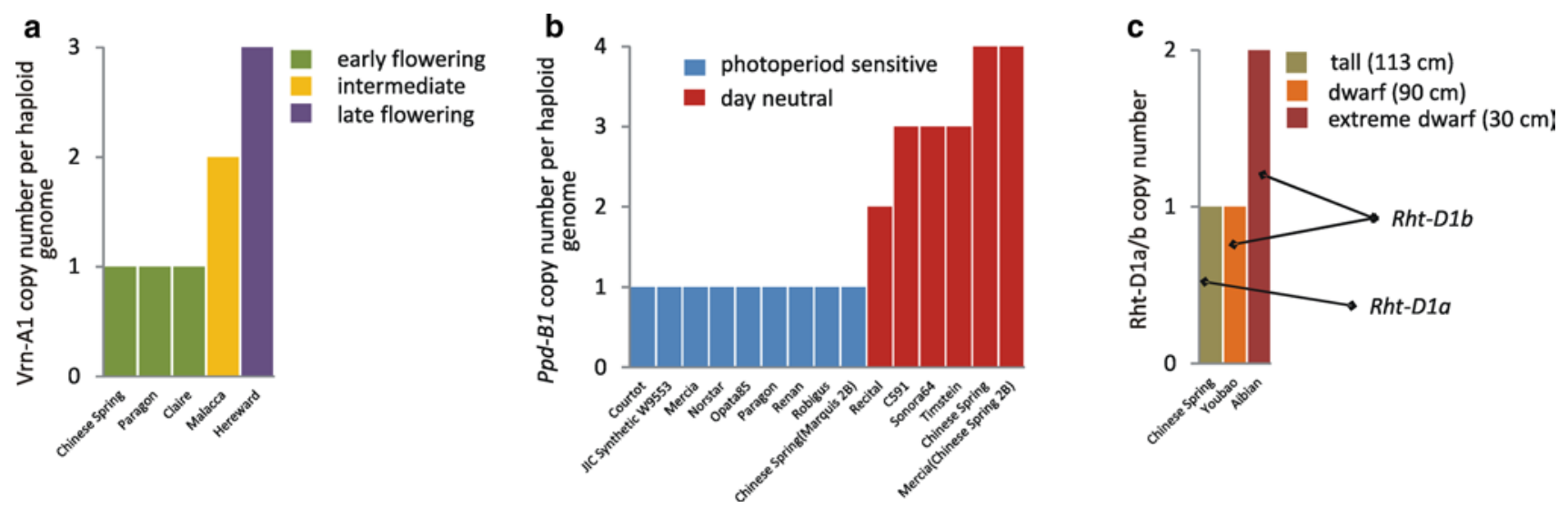

Fig. 2 Gene $\mathrm{CNV}$ contributes to wheat phenotypic diversity. a CNV of $V r n-A l$ gene controls flowering time by affecting vernalization requirement; $\mathbf{b} \mathrm{CNV}$ of $P p d-B 1$ controls flowering time by affecting photoperiod sensitivity; $\mathbf{c} \mathrm{CNV}$ of $R h t-D l b$ gene (a truncated version of Rht-Dla) determines severity of plant dwarfism phenotype. In all three cases, the impact of gene copy number on observed phenotype has been verified experimentally. Source data: a, b Díaz et al. (2012); c Li et al. (2012)

a

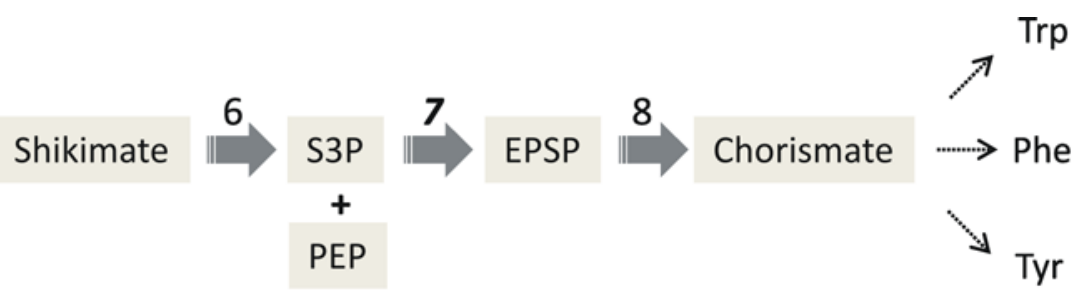

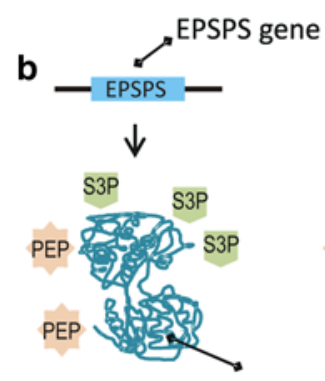

EPSPS enzyme

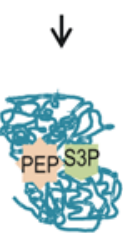

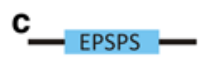
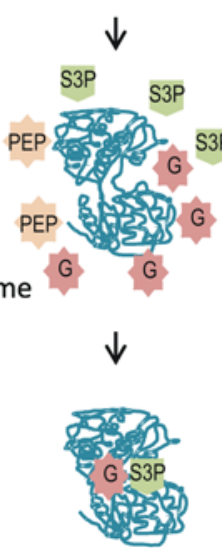

d
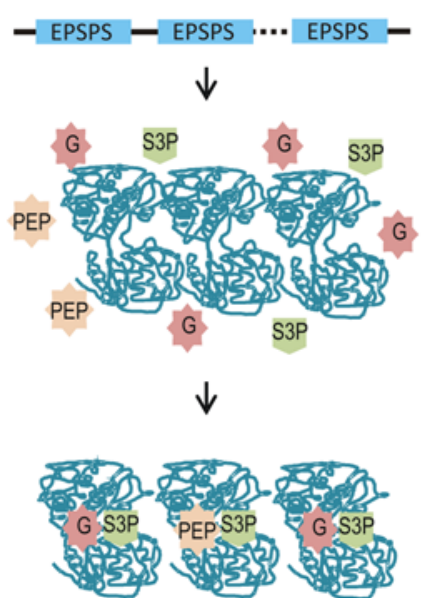

e

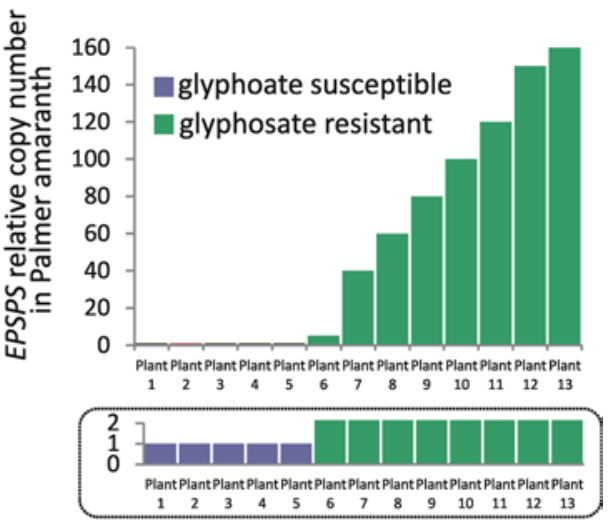

Fig. 3 Glyphosate resistance in Palmer amaranth mediated by CNV of EPSPS gene. a Graphical representation of the shikimate pathway. Step 7 is catalyzed by EPSPS enzyme; b-d mechanism of EPSPS inhibition by glyphosate and its overcoming by increased number of EPSPS gene copies. In absence of glyphosate, PEP and S3P bind to EPSPS (b). When glyphosate is present, it competitively binds to EPSPS, mimicking an intermediate state of the ternary enzyme-substrates complex and inhibiting EPSPS (c). Amplification of EPSPS

The EPSPS gene CNV is not unique to Palmer amaranth. Recent and rapid increases in glyphosate resistance in common waterhemp (Amaranthus tuberculatus) and Arkansas gene leads to production of additional protein molecules and PEP binding, even in presence of glyphosate (d). e Differences in EPSPS gene copy number between glyphosate susceptible and glyphosateresistant Palmer amaranth individuals. EPSPS 5-enolpyruvylshikimate-3-phosphate synthase, $P E P$ phosphoenol pyruvate, $S 3 P$ shikimate-3-phosphate, EPSP 5-enolpyruvylshikimate 3-phosphate, $G$ glyphosate

populations of Italian ryegrass (Lolium perenne ssp. multiflorum) have been attributed to increased copy number of EPSPS in those plants as well (Tranel et al. 2011; Salas 
et al. 2012). The EPSPS example shows that the accumulation of copy number changes may serve as a mechanism of extremely rapid evolution under high selection pressure. In the case of Palmer amaranth, the random distribution of EPSPS gene copies in the genome (as observed by FISH experiments) suggests the involvement of transposable elements in the creation of new EPSPS gene copies (Gaines et al. 2010). Mobile genetic elements might have been induced and/or supported by the very strong selective pressure resulting from extensive glyphosate treatment, leading to duplication and transfer of a nearby EPSPS gene.

\section{Outlook}

Recent genome-scale studies indicate that CNV significantly contributes to natural variation of plants. Accordingly, one can expect that CNVs play significant roles in plant evolution and adaptation. There is no doubt that the research on CNV phenomenon in plant is still at its beginning but we envision its dynamic development in the nearest future. Highly inbred and genetically homogenous plant cultivars seem to be perfect models for studying general and plant-specific aspects of CNV. This is especially true for Arabidopsis, a self-compatible plant with a small genome and a plenty of genetic tools, such as RILs (recombinant inbred lines) and MAGIC (multiple advanced generation intercross) already available (Weigel 2012).

We expect a growing approbation of CNV's impact on plant phenotype, both in the aspect of long-term evolution as well as a mechanism of rapid adaptation to environmental challenges. Crops, which underwent fast phenotypic transformation under strong selective pressure related to domestication, may be excellent models for studying the general role of CNV in adaptation. This problem seems to be especially interesting in the context of recent reports suggesting that rapid copy number expansion of genes involved in resistance to herbicides or drugs, may take place (reviewed in Kondrashov 2012). In many such cases, CNV affected the same key genes independently in various populations or even independently in different species (Triglia et al. 1991; Widholm et al. 2001; Labbé et al. 2007; Gaines et al. 2010; Tranel et al. 2011; Salas et al. 2012). In addition, recurrent gene deletions have been observed in plants and animals, highlighting the role of presenceabsence variation in rapid adaptive evolution (McGrath et al. 2011; Olsen and Wendel 2013). Those examples allow to hypothesize that $\mathrm{CNV}$ phenomenon may be successfully employed for directional plant improvement.

Links between $\mathrm{CNVs}$ and phenotypic variation also suggest that CNVs can be utilized in genome-wide association studies (GWAS), which are now based mostly on SNPs (Atwell et al. 2010). Indeed, association analysis of
5 traits involved in leaf development and disease resistance in 103 maize lines using both SNPs and CNVs revealed that CNVs contribute greatly to the variation of analyzed phenotypes and provide complementary information to SNPs (Chia et al. 2012). However, to enable the use of SNP and CNV markers by the community, integrated plant genomic variant catalogs, similar to the human Database of Genomic Variants, are needed. Increasing accessibility of NGS techniques makes such databases likely to be created in the nearest future. Still, the main limitation of NGSbased CNV discovery is lack of well-established pipelines for data analysis and imperfection of the current software to correct for technical bias in the sequence data. There are observations (including our own unpublished results) that utilizing different software for read mapping and/or CNV calling from the same sequence data, results in lists of variants which have little overlap with each other (Alkan et al. 2011). Thus, to confirm the accuracy of genome-scale CNV discovery from NGS data, variant calling should be routinely followed by experimental verification of a large fraction of inferred CNVs using one or more molecular genotyping assays (Cantsilieris et al. 2012). Currently, this process is usually limited to relatively easy verification of presence-absence variants.

Acknowledgments Funding from the National Science Centre (Grants No. UMO-2011/01/B/NZ2/04816 to MF and 2011/01/B/NZ5/ 02773 to $\mathrm{PK})$ is acknowledged.

Conflict of interest The authors declare no conflict of interest.

Open Access This article is distributed under the terms of the Creative Commons Attribution License which permits any use, distribution, and reproduction in any medium, provided the original author(s) and the source are credited.

\section{References}

Alkan C, Coe BP, Eichler EE (2011) Genome structural variation discovery and genotyping. Nat Rev Genet 12(5):363-376. doi:10.1038/nrg2958

Armour JA, Sismani C, Patsalis PC, Cross G (2000) Measurement of locus copy number by hybridisation with amplifiable probes. Nucleic Acids Res 28:605-609. doi:10.1093/nar/28.2.605

Armour JA, Palla R, Zeeuwen PL, den Heijer M, Schalkwijk J, Hollox EJ (2007) Accurate, high-throughput typing of copy number variation using paralogue ratios from dispersed repeats. Nucleic Acids Res 35:e19. doi:10.1093/nar/gk11089

Ashfield T, Egan AN, Pfeil BE, Chen NW, Podicheti R, Ratnaparkhe MB, Ameline-Torregrosa C, Denny R, Cannon S, Doyle JJ, Geffroy V, Roe BA, Saghai Maroof MA, Young ND, Innes RW (2012) Evolution of a complex disease resistance gene cluster in diploid Phaseolus and tetraploid Glycine. Plant Physiol 159:336354. doi:10.1104/pp.112.195040

Atwell S, Huang YS, Vilhjálmsson BJ, Willems G, Horton M, Li Y, Meng D, Platt A, Tarone AM, Hu TT, Jiang R, Muliyati NW, Zhang X, Amer MA, Baxter I, Brachi B, Chory J, Dean C, 
Debieu M, de Meaux J, Ecker JR, Faure N, Kniskern JM, Jones JD, Michael T, Nemri A, Roux F, Salt DE, Tang C, Todesco M, Traw MB, Weigel D, Marjoram P, Borevitz JO, Bergelson J, Nordborg M (2010) Genome-wide association study of 107 phenotypes in Arabidopsis thaliana inbred lines. Nature 465:627-631. doi: 10.1038 /nature 08800

Aubry C, R. Shoal, Erickson V (2005) Grass cultivars: their origins, development, and use on national forests and grasslands in the Pacific Northwest. USDA Forest Service. http://www.fs. fed.us/wildflowers/nativeplantmaterials/documents/ cultivars_maindoc_040405_appendices.pdf (Accessed 7 March 2013)

Beló A, Beatty MK, Hondred D, Fengler KA, Li B, Rafalski A (2010) Allelic genome structural variations in maize detected by array comparative genome hybridization. Theor Appl Genet 120:355367. doi:10.1007/s00122-009-1128-9

Bickhart DM, Hou Y, Schroeder SG, Alkan C, Cardone MF, Matukumalli LK, Song J, Schnabel RD, Ventura M, Taylor JF, Garcia JF, Van Tassell CP, Sonstegard TS, Eichler EE, Liu GE (2012) Copy number variation of individual cattle genomes using nextgeneration sequencing. Genome Res 22:778-790. doi:10.1101 /gr.133967.111

Canaran P, Buckler ES, Glaubitz JC, Stein L, Sun Q, Zhao W, Ware D (2008) Panzea: an update on new content and features. Nucleic Acids Res 36:D1041-D1043. doi:10.1093/nar/gkm1022

Cantsilieris S, Baird PN, White SJ (2012) Molecular methods for genotyping complex copy number polymorphisms. Genomics 101:86-93. doi:10.1016/j.ygeno.2012.10.004

Cao J, Schneeberger K, Ossowski S, Günther T, Bender S, Fitz J, Koenig D, Lanz C, Stegle O, Lippert C, Wang X, Ott F, Müller J, Alonso-Blanco C, Borgwardt K, Schmid KJ, Weigel D (2011) Whole-genome sequencing of multiple Arabidopsis thaliana populations. Nat Genet 43:956-963. doi:10.1038/ng.911

Chia JM, Song C, Bradbury PJ, Costich D, de Leon N, Doebley J, Elshire RJ, Gaut B, Geller L, Glaubitz JC, Gore M, Guill KE, Holland J, Hufford MB, Lai J, Li M, Liu X, Lu Y, McCombie R, Nelson R, Poland J, Prasanna BM, Pyhäjärvi T, Rong T, Sekhon RS, Sun Q, Tenaillon MI, Tian F, Wang J, Xu X, Zhang Z, Kaeppler SM, Ross-Ibarra J, McMullen MD, Buckler ES, Zhang G, Xu Y, Ware D (2012) Maize HapMap2 identifies extant variation from a genome in flux. Nat Genet 44:803-807. doi:10.1038/ ng. 2313

Conrad DF, Pinto D, Redon R, Feuk L, Gokcumen O, Zhang Y, Aerts J, Andrews TD, Barnes C, Campbell P, Fitzgerald T, Hu M, Ihm CH, Kristiansson K, Macarthur DG, Macdonald JR, Onyiah I, Pang AW, Robson S, Stirrups K, Valsesia A, Walter K, Wei J, Tyler-Smith C, Carter NP, Lee C, Scherer SW, Hurles ME, Wellcome Trust Case Control Consortium (2010) Origins and functional impact of copy number variation in the human genome. Nature 464:704-712 10.1038/nature08516

Cook DE, Lee TG, Guo X, Melito S, Wang K, Bayless AM, Wang J, Hughes TJ, Willis DK, Clemente TE, Diers BW, Jiang J, Hudson ME, Bent AF (2012) Copy number variation of multiple genes at Rhg1 mediates nematode resistance in soybean. Science 338:1206-1209. doi:10.1126/science. 1228746

Culpepper AS, Grey TL, Vencill WK, Kichler JM, Webster TM, Brown SM, York AC, Davis JW, Hanna WW (2006) Glyphosateresistant Palmer amaranth (Amaranthus palmeri) confirmed in Georgia. Weed Sci 54:620-626. doi:10.1614/WS-06-001R.1

Daines B, Wang H, Li Y, Han Y, Gibbs R, Chen R (2009) Highthroughput multiplex sequencing to discover copy number variants in Drosophila. Genetics 182:935-941. doi:10.1534/ genetics.109.103218

DeBolt S (2010) Copy number variation shapes genome diversity in Arabidopsis over immediate family generational scales. Genome Biol Evol 2:441-453. doi:10.1093/gbe/evq033
Díaz A, Zikhali M, Turner AS, Isaac P, Laurie DA (2012) Copy number variation affecting the photoperiod-BI and vernalization-Al genes is associated with altered flowering time in wheat (Triticum aestivum). PLoS ONE 7:e33234. doi:10.1371/ journal.pone.0033234

Dohm JC, Lottaz C, Borodina T, Himmelbauer H (2008) Substantial biases in ultra-short read data sets from high-throughput DNA sequencing. Nucleic Acids Res 36:e105. doi:10.1093/nar/gkn425

Emerson JJ, Cardoso-Moreira M, Borevitz JO, Long M (2008) Natural selection shapes genome-wide patterns of copy-number polymorphism in Drosophila melanogaster. Science 320:1629-1631. doi:10.1126/science. 1158078

Frank B, Bermejo JL, Hemminki K, Sutter C, Wappenschmidt B et al (2007) Copy number variant in the candidate tumor suppressor gene MTUS1 and familial breast cancer risk. Carcinogenesis 28:1442-1445. doi:10.1093/carcin/bgm033

Gaines TA, Zhang W, Wang D, Bukun B, Chisholm ST, Shaner DL, Nissen SJ, Patzoldt WL, Tranel PJ, Culpepper AS, Grey TL, Webster TM, Vencill WK, Sammons RD, Jiang J, Preston C, Leach JE, Westra P (2010) Gene amplification confers glyphosate resistance in Amaranthus palmeri. Proc Natl Acad Sci USA 107:1029-1034. doi:10.1073/pnas.0906649107

Gaines TA, Shaner DL, Ward SM, Leach JE, Preston C, Westra P (2011) Mechanism of resistance of evolved glyphosate-resistant Amaranthus palmeri. J Agric Food Chem 59:5886-5889. doi:10.1021/jf104719k

Garris AJ, Tai TH, Coburn J, Kresovich S, McCouch S (2005) Genetic structure and diversity in Oryza sativa L. Genetics 169:16311638. doi:10.1534/genetics.104.035642

Girirajan S, Johnson RL, Tassone F, Balciuniene J, Katiyar N, Fox K, Baker C, Srikanth A, Yeoh KH, Khoo SJ, Nauth TB, Hansen R, Ritchie M, Hertz-Picciotto I, Eichler EE, Pessah IN, Selleck SB (2013) Global increases in both common and rare copy number load associated with autism. Hum Mol Genet. doi:10.1093/hmg/ ddt136

Gonzalez E, Kulkarni H, Bolivar H, Mangano A, Sanchez R, Catano G, Nibbs RJ, Freedman BI, Quinones MP, Bamshad MJ et al (2005) The influence of CCL3L1 gene-containing segmental duplications on HIV-1/AIDS susceptibility. Science 307:14341440. doi:10.1126/science. 1101160

Gore MA, Chia JM, Elshire RJ, Sun Q, Ersoz ES, Hurwitz BL, Peiffer JA, McMullen MD, Grills GS, Ross-Ibarra J, Ware DH, Buckler ES (2009) A first-generation haplotype map of maize. Science 326:1115-1117. doi:10.1126/science. 1177837

Gu W, Zhang F, Lupski JR (2008) Mechanisms for human genomic rearrangements. Pathogenetics 1:4. doi:10.1186/1755-8417-1-4

Guo YL, Fitz J, Schneeberger K, Ossowski S, Cao J, Weigel D (2011) Genome-wide comparison of nucleotide-binding site-leucine-rich repeat-encoding genes in Arabidopsis. Plant Physiol 157:757769. doi:10.1104/pp.111.181990

Han JJ, Jackson D, Martienssen R (2012) Pod corn is caused by rearrangement at the Tunicate1 locus. Plant Cell 24:2733-2744. doi:1 $0.1105 /$ tpc. 112.100537

Hansey CN, Vaillancourt B, Sekhon RS, de Leon N, Kaeppler SM, Buell CR (2012) Maize (Zea mays L.) genome diversity as revealed by RNA-sequencing. PLoS ONE 7:e33071. doi:10.1371/ journal.pone.0033071

Haun WJ, Hyten DL, Xu WW, Gerhardt DJ, Albert TJ, Richmond T, Jeddeloh JA, Jia G, Springer NM, Vance CP, Stupar RM (2011) The composition and origins of genomic variation among individuals of the soybean reference cultivar Williams 82. Plant Physiol 155:645-655. doi:10.1104/pp.110.166736

Helbig I, Mefford HC, Sharp AJ, Guipponi M, Fichera M, Franke A et al (2009) 15q13.3 microdeletions increase risk of idiopathic generalized epilepsy. Nat Genet 41:160-162. doi:10.1038/ ng. 292 
Herrmann KM (1995) The shikimate pathway: early steps in the biosynthesis of aromatic compounds. Plant Cell 7:907-919. doi: $10.2307 / 3870046$

Hollox EJ, Huffmeier U, Zeeuwen PL, Palla R, Lascorz J, Rodijk-Olthuis D, van de Kerkhof PC, Traupe H, de Jongh G, den Heijer M, Reis A, Armour JA, Schalkwijk J (2008) Psoriasis is associated with increased beta-defensin genomic copy number. Nat Genet 40:23-25

Huang X, Wei X, Sang T, Zhao Q, Feng Q, Zhao Y, Li C, Zhu C, Lu T, Zhang Z, Li M, Fan D, Guo Y, Wang A, Wang L, Deng L, Li W, Lu Y, Weng Q, Liu K, Huang T, Zhou T, Jing Y, Li W, Lin Z, Buckler ES, Qian Q, Zhang QF, Li J, Han B (2010) Genomewide association studies of 14 agronomic traits in rice landraces. Nat Genet 42:961-967. doi:10.1038/ng.695

Huang X, Kurata N, Wei X, Wang ZX, Wang A, Zhao Q, Zhao Y, Liu K, Lu H, Li W, Guo Y, Lu Y, Zhou C, Fan D, Weng Q, Zhu C, Huang T, Zhang L, Wang Y, Feng L, Furuumi H, Kubo T, Miyabayashi T, Yuan X, Xu Q, Dong G, Zhan Q, Li C, Fujiyama A, Toyoda A, Lu T, Feng Q, Qian Q, Li J, Han B (2012) A map of rice genome variation reveals the origin of cultivated rice. Nature 490:497-501. doi:10.1038/nature 11532

Huang X, Lu T, Han B (2013) Resequencing rice genomes: an emerging new era of rice genomics. Trends Genet 29:225-232. doi:10.1016/j.tig.2012.12.001

Iafrate AJ, Feuk L, Rivera MN, Listewnik ML, Donahoe PK, Qi Y, Scherer SW, Lee C (2004) Detection of large-scale variation in the human genome. Nat Genet 36:949-951. doi:10.1038/ng1416

Iovene M, Zhang T, Lou Q, Buell CR, Jiang J (2013) Copy number variation in potato - an asexually propagated autotetraploid species. Plant J 75:80-89. doi:10.1111/tpj.12200

Jeong IS, Yoon UH, Lee GS, Ji HS, Lee HJ, Han CD, Hahn JH, An G, Kim TH (2013) SNP-based analysis of genetic diversity in anther-derived rice by whole genome sequencing. Rice 6:6. doi:10.1186/1939-8433-6-6

Knox AK, Dhillon T, Cheng H, Tondelli A, Pecchioni N, Stockinger EJ (2010) CBF gene copy number variation at Frost Resistance-2 is associated with levels of freezing tolerance in temperate-climate cereals. Theor Appl Genet 121:21-35. doi:10.1007/ s00122-010-1288-7

Kondrashov FA (2012) Gene duplication as a mechanism of genomic adaptation to a changing environment. Proc Biol Sci 279:50485057. doi:10.1098/rspb.2012.1108

Korbel JO, Kim PM, Chen X, Urban AE, Weissman S, Snyder M, Gerstein MB (2008) The current excitement about copy-number variation: how it relates to gene duplications and protein families. Curr Opin Struct Biol 18:366-374. doi:10.1016/j.sbi.2008.02.005

Labbé P, Berthomieu A, Berticat C, Alout H, Raymond M, Lenormand T, Weill M (2007) Independent duplications of the acetylcholinesterase gene conferring insecticide resistance in the mosquito Culex pipiens. Mol Biol Evol 24:1056-1067

Lai J, Li R, Xu X, Jin W, Xu M, Zhao H, Xiang Z, Song W, Ying K, Zhang M, Jiao Y, Ni P, Zhang J, Li D, Guo X, Ye K, Jian M, Wang B, Zheng H, Liang H, Zhang X, Wang S, Chen S, Li J, Fu Y, Springer NM, Yang H, Wang J, Dai J, Schnable PS, Wang J (2010) Genome-wide patterns of genetic variation among elite maize inbred lines. Nat Genet 42:1027-1030. doi:10.1038/ng.684

Lam HM, Xu X, Liu X, Chen W, Yang G, Wong FL, Li MW, He W, Qin N, Wang B, Li J, Jian M, Wang J, Shao G, Wang J, Sun SS, Zhang G (2010) Resequencing of 31 wild and cultivated soybean genomes identifies patterns of genetic diversity and selection. Nat Genet 42:1053-1059. doi:10.1038/ng.715

Lee JA, Carvalho CM, Lupski JR (2007a) A DNA replication mechanism for generating nonrecurrent rearrangements associated with genomic disorders. Cell 131:1235-1247. doi:10.1016/j.cell.2007.11.037

Lee C, Iafrate AJ, Brothman AR (2007b) Copy number variations and clinical cytogenetic diagnosis of constitutional disorders. Nat Genet 39:S48-S54. doi:10.1038/ng2092
Li Y, Xiao J, Wu J, Duan J, Liu Y, Ye X, Zhang X, Guo X, Gu Y, Zhang L, Jia J, Kong X (2012) A tandem segmental duplication (TSD) in green revolution gene Rht-Dlb region underlies plant height variation. New Phytol 196:282-291. doi:10.1111/j.1469-8137.2012.04243.x

Liao HM, Chao YL, Huang AL, Cheng MC, Chen YJ, Lee KF, Fang JS, Hsu CH, Chen CH (2012) Identification and characterization of three inherited genomic copy number variations associated with familial schizophrenia. Schizophr Res 139:229-236. doi:10.1016/j.schres.2012.05.015

Lu P, Han X, Qi J, Yang J, Wijeratne AJ, Li T, Ma H (2012) Analysis of Arabidopsis genome-wide variations before and after meiosis and meiotic recombination by resequencing Landsberg erecta and all four products of a single meiosis. Genome Res 22:508518. doi:10.1101/gr.127522.111

Luo S, Zhang Y, Hu Q, Chen J, Li K, Lu C, Liu H, Wang W, Kuang H (2012) Dynamic nucleotide-binding site and leucine-rich repeatencoding genes in the grass family. Plant Physiol 159:197-210. doi:10.1104/pp.111.192062

Ma J, Bennetzen JL (2004) Rapid recent growth and divergence of rice nuclear genomes. Proc Natl Acad Sci USA 101:1240412410. doi:10.1073/pnas.0403715101

Marcinkowska-Swojak M, Uszczynska B, Figlerowicz M, Kozlowski P (2013) An MLPA-based strategy for discrete CNV genotyping: CNV-miRNAs as an example. Hum Mutat 34:763-773. doi:10.1 002/humu.22288

Maron LG, Guimarães CT, Kirst M, Albert PS, Birchler JA, Bradbury PJ, Buckler ES, Coluccio AE, Danilova TV, Kudrna D, Magalhaes JV, Piñeros MA, Schatz MC, Wing RA, Kochian LV (2013) Aluminum tolerance in maize is associated with higher MATE1 gene copy number. Proc Natl Acad Sci USA 110:5241-5246. doi: 10.1073/pnas.1220766110

McGrath PT, Xu Y, Ailion M, Garrison JL, Butcher RA, Bargmann CI (2011) Parallel evolution of domesticated Caenorhabditis species targets pheromone receptor genes. Nature 477:321-325. doi:10.1038/nature 10378

McHale LK, Haun WJ, Xu WW, Bhaskar PB, Anderson JE, Hyten DL, Gerhardt DJ, Jeddeloh JA, Stupar RM (2012) Structural variants in the soybean genome localize to clusters of biotic stressresponse genes. Plant Physiol 159:1295-1308. doi:10.1104/ pp.112.194605

Medvedev P, Stanciu M, Brudno M (2009) Computational methods for discovering structural variation with next-generation sequencing. Nat Methods 6:S13-S20. doi:10.1038/nmeth.1374

Mills RE, Walter K, Stewart C, Handsaker RE, Chen K, Alkan C, Abyzov A, Yoon SC, Ye K, Cheetham RK, Chinwalla A, Con$\operatorname{rad}$ DF, Fu Y, Grubert F, Hajirasouliha I, Hormozdiari F, Iakoucheva LM, Iqbal Z, Kang S, Kidd JM, Konkel MK, Korn J, Khurana E, Kural D, Lam HY, Leng J, Li R, Li Y, Lin CY, Luo R, Mu XJ, Nemesh J, Peckham HE, Rausch T, Scally A, Shi X, Stromberg MP, Stütz AM, Urban AE, Walker JA, Wu J, Zhang Y, Zhang ZD, Batzer MA, Ding L, Marth GT, McVean G, Sebat J, Snyder M, Wang J, Ye K, Eichler EE, Gerstein MB, Hurles ME, Lee C, McCarroll SA, Korbel JO (2011) 1000 Genomes Project. Mapping copy number variation by population-scale genome sequencing. Nature 470:59-65. doi:10.1038/nature09708

Olsen KM, Wendel JF (2013) Crop plants as models for understanding plant adaptation and diversification. Front Plant Sci. 4:290. doi:10.3389/fpls.2013.00290

Ossowski S, Schneeberger K, Lucas-Lledó JI, Warthmann N, Clark RM, Shaw RG, Weigel D, Lynch M (2010) The rate and molecular spectrum of spontaneous mutations in Arabidopsis thaliana. Science 327:92-94. doi:10.1126/science.1180677

Pankratz N, Dumitriu A, Hetrick KN, Sun M, Latourelle JC, Wilk JB, Halter C, Doheny KF, Gusella JF, Nichols WC, Myers RH, Foroud T, DeStefano AL, PSG-PROGENI and GenePD 
Investigators, Coordinators and Molecular Genetic Laboratories (2011) Copy number variation in familial Parkinson disease. PLoS ONE 6:e20988. doi:10.1371/journal.pone.0020988

Pearce S, Saville R, Vaughan SP, Chandler PM, Wilhelm EP, Sparks CA, Al-Kaff N, Korolev A, Boulton MI, Phillips AL, Hedden P, Nicholson P, Thomas SG (2011) Molecular characterization of Rht-1 dwarfing genes in hexaploid wheat. Plant Physiol 157:1820-1831. doi:10.1104/pp.111.183657

Redon R, Ishikawa S, Fitch KR, Feuk L, Perry GH, Andrews TD, Fiegler H, Shapero MH, Carson AR, Chen W, Cho EK, Dallaire S, Freeman JL, Gonzalez JR, Gratacos M, Huang J, Kalaitzopoulos D, Komura D, MacDonald JR, Marshall CR, Mei R, Montgomery L, Nishimura K, Okamura K, Shen F, Somerville MJ, Tchinda J, Valsesia A, Woodwark C, Yang F, Zhang J, Zerjal T, Zhang J, Armengol L, Conrad DF, Estivill X, Tyler-Smith C, Carter NP, Aburatani H, Lee C, Jones KW, Scherer SW, Hurles ME (2006) Global variation in copy number in the human genome. Nature 444:444-454. doi:10.1038/nature05329

Rovelet-Lecrux A, Hannequin D, Raux G, Le Meur N, Laquerrière A, Vital A, Dumanchin C, Feuillette S, Brice A, Vercelletto M, Dubas F, Frebourg T, Campion D (2006) APP locus duplication causes autosomal dominant early-onset Alzheimer disease with cerebral amyloid angiopathy. Nat Genet 38:24-26. doi:10.1038/ ng1718

Saintenac C, Jiang D, Akhunov ED (2011) Targeted analysis of nucleotide and copy number variation by exon capture in allotetraploid wheat genome. Genome Biol 12:R88. doi:10.1186/gb-2011-12-9-r88

Salas RA, Dayan FE, Pan Z, Watson SB, Dickson JW, Scott RC, Burgos NR (2012) EPSPS gene amplification in glyphosate-resistant Italian ryegrass (Lolium perenne ssp. multiflorum) from Arkansas. Pest Manag Sci 68:1223-1230. doi:10.1002/ps.3342

Santuari L et al (2010) Substantial deletion overlap among divergent Arabidopsis genomes revealed by intersection of short reads and tiling arrays. Genome Biol 11:R4

Schnable PS, Ware D, Fulton RS, Stein JC, Wei F, Pasternak S, Liang C, Zhang J, Fulton L et al (2009) The B73 maize genome: complexity, diversity, and dynamics. Science 326:1112-1115. doi:10.1126/science.1178534

Schönbrunn E, Eschenburg S, Shuttleworth WA, Schloss JV, Amrhein N, Evans JN, Kabsch W (2001) Interaction of the herbicide glyphosate with its target enzyme 5-enolpyruvylshikimate 3-phosphate synthase in atomic detail. Proc Natl Acad Sci USA 98:1376-1380. doi:10.1073/pnas.98.4.1376

Sebat J, Lakshmi B, Troge J, Alexander J, Young J, Lundin P, Maner S, Massa H, Walker M, Chi M, Navin N, Lucito R, Healy J, Hicks J, Ye K, Reiner A, Gilliam TC, Trask B, Patterson N, Zetterberg A, Wigler M (2004) Large-scale copy number polymorphism in the human genome. Science 305:525-528. doi:10.1126/ science. 1098918

Shlien A, Tabori U, Marshall CR, Pienkowska M, Feuk L, Novokmet A, Nanda S, Druker H, Scherer SW, Malkin D (2008) Excessive genomic DNA copy number variation in the Li-Fraumeni cancer predisposition syndrome. Proc Natl Acad Sci USA 105:1126411269. doi:10.1073/pnas.0802970105

Springer NM, Ying K, Fu Y, Ji T, Yeh CT, Jia Y, Wu W, Richmond T, Kitzman J, Rosenbaum H, Iniguez AL, Barbazuk WB, Jeddeloh JA, Nettleton D, Schnable PS (2009) Maize inbreds exhibit high levels of copy number variation (CNV) and presence/absence variation (PAV) in genome content. PLoS Genet 5:e1000734. doi:10.1371/journal.pgen.1000734

Stadler Z, Esposito D, Shah S, Vijai J, Yamrom B, Levy D et al (2012) Rare de novo germline copy-number variation in testicular cancer. Am J Hum Genet 91(2):379-383. doi:10.1016/j.ajhg.2012.06.019

Stankiewicz P, Lupski JR (2010) Structural variation in the human genome and its role in disease. Annu Rev Med 61:437-455. doi:10.1146/annurev-med-100708-204735
Stefansson H, Rujescu D, Cichon S, Pietiläinen OP, Ingason A, Steinberg S et al (2008) Large recurrent microdeletions associated with schizophrenia. Nature 455:232-236. doi:10.1038/nature07229

Sutton T, Baumann U, Hayes J, Collins NC, Shi BJ, Schnurbusch T, Hay A, Mayo G, Pallotta M, Tester M, Langridge P (2007) Borontoxicity tolerance in barley arising from efflux transporter amplification. Science 318:1446-1449. doi:10.1126/science.1146853

Swanson-Wagner RA, Eichten SR, Kumari S, Tiffin P, Stein JC, Ware D, Springer NM (2010) Pervasive gene content variation and copy number variation in maize and its undomesticated progenitor. Genome Res 20:1689-1699. doi:10.1101/gr.109165.110

Tranel PJ, Riggins CW, Bell MS, Hager AG (2011) Herbicide resistances in Amaranthus tuberculatus: a call for new options. J Agric Food Chem 59:5808-5812. doi:10.1021/jf103797n

Treangen TJ, Salzberg SL (2011) Repetitive DNA and next-generation sequencing: computational challenges and solutions. Nat Rev Genet 13:36-46. doi:10.1038/nrg3117

Triglia T, Foote SJ, Kemp DJ, Cowman AF (1991) Amplification of the multidrug resistance gene pfmdr1 in Plasmodium falciparum has arisen as multiple independent events. Mol Cell Biol 11:5244-5250

Warren AS, Anandakrishnan R, Zhang L (2010) Functional bias in molecular evolution rate of Arabidopsis thaliana. BMC Evol Biol 10:125. doi:10.1186/1471-2148-10-125

Weaver S, Dube S, Mir A, Qin J, Sun G, Ramakrishnan R, Jones RC, Li-vak KJ (2010) Taking qPCR to a higher level: analysis of $\mathrm{CNV}$ reveals the power of high throughput qPCR to enhance quantitative resolution. Methods 50:271-276. doi:10.1016/ j.ymeth.2010.01.003

Weigel D (2012) Natural variation in Arabidopsis: from molecular genetics to ecological genomics. Plant Physiol 158:2-22. doi:10.1104/pp.111.189845

Weigel D, Mott R (2009) The 1001 genomes project for Arabidopsis thaliana. Genome Biol 10:107. doi:10.1186/gb-2009-10-5-107

Weiss LA, Shen Y, Korn JM, DE Arking, Miller DT, Fossdal R, Saemundsen E, Stefansson H, Ferreira MA, Green T, Platt OS, Ruderfer DM, Walsh CA, Altshuler D, Chakravarti A, Tanzi RE, Stefansson K, Santangelo SL, Gusella JF, Sklar P, Wu BL, Daly MJ, Autism Consortium (2008) Association between microdeletion and microduplication at 16p11.2 and Autism. N Engl J Med 358:667-675 10.1056/NEJMoa075974

Widholm JM, Chinnala AR, Ryu JH, Song HS, Eggett T, Brotherton JE (2001) Glyphosate selection of gene amplification in suspension cultures of 3 plant species. Physiol Plant 112:540-545. doi:10.1034/j.1399-3054.2001.1120411.x

Wingen LU, Münster T, Faigl W, Deleu W, Sommer H, Saedler H, Theißen G (2012) Molecular genetic basis of pod corn (Tunicate maize). Proc Natl Acad Sci USA 109:7115-7120. doi:10.1073/p nas. 1111670109

Xu K, Xu X, Fukao T, Canlas P, Maghirang-Rodriguez R, Heuer S, Ismail AM, Bailey-Serres J, Ronald PC, Mackill DJ (2006) Sub1A is an ethylene-response-factor-like gene that confers submergence tolerance to rice. Nature 442:705-708. doi:10.1038/ nature 04920

Xu X, Liu X, Ge S, Jensen JD, Hu F, Li X, Dong Y, Gutenkunst RN, Fang L, Huang L, Li J, He W, Zhang G, Zheng X, Zhang F, Li Y, Yu C, Kristiansen K, Zhang X, Wang J, Wright M, McCouch S, Nielsen R, Wang J, Wang W (2011) Resequencing 50 accessions of cultivated and wild rice yields markers for identifying agronomically important genes. Nat Biotechnol 30:105-111. doi:10.1038/nbt.2050

Yang TL, Chen XD, Guo Y, Lei SF, Wang JT, Zhou Q, Pan F, Chen Y, Zhang ZX, Dong SS et al (2008) Genome-wide copy-number-variation study identified a susceptibility gene, UGT2B17, for osteoporosis. Am J Hum Genet 83:663-674. doi:10.1016/ j.ajhg.2008.10.006 
Yau C, Holmes CC (2008) CNV discovery using SNP genotyping arrays. Cytogenet Genome Res 123:307-312. doi:10.1159/ 000184722

Yoon S, Xuan Z, Makarov V, Ye K, Sebat J (2009) Sensitive and accurate detection of copy number variants using read depth of coverage. Genome Res 19:1586-1592. doi:10.1101/gr.092981.109

Yoshihara K, Tajima A, Adachi S, Quan J, Sekine M, Kase H, Yahata T, Inoue I, Tanaka K (2011) Germline copy number variations in BRCA1-associated ovarian cancer patients. Genes Chromosomes Cancer 50:167-177. doi:10.1002/gcc.20841

Yu P, Wang C, Xu Q, Feng Y, Yuan X, Yu H, Wang Y, Tang S, Wei $X$ (2011) Detection of copy number variations in rice using array-based comparative genomic hybridization. BMC Genomics 12:372. doi:10.1186/1471-2164-12-372

Zhang F, Khajavi M, Connolly AM, Towne CF, Batish SD, Lupski JR (2009) The DNA replication FoSTeS/MMBIR mechanism can generate human genomic, genic, and exonic complex rearrangements. Nat Genet 41:849-853. doi:10.1038/ng.399

Zheng LY, Guo XS, He B, Sun LJ, Peng Y, Dong SS, Liu TF, Jiang S, Ramachandran S, Liu CM, Jing HC (2011) Genomewide patterns of genetic variation in sweet and grain sorghum (Sorghum bicolor). Genome Biol 12:R114. doi:10.1186/ gb-2011-12-11-r114 